\title{
LAYANAN INFORMASI PUBLIK DAN PARTISIPASI PUBLIK
}

\author{
Suryani \\ STISIPOL PAHLAWAN 12, J1. Diponegoro No. 16, Sungailiat, Bangka 33215 \\ Telp/Fax. (0717) 92750
}

\begin{abstract}
ABSTRAK
Layanan informasi publik merupakan satu konsep dasar pemerintah untuk melaksanakan amanat Undang-Undang 1945, dalam menyiapkan segala akses komunikasi dan informasi dengan menyediakan segala jenis saluran yang tersedia. Baik melalui media pos dan telekomunikasi, penyiaran, media komunikasi sosial dan media massa serta berbagai media yang bersifat interpersonal sebagai bagian dari perwujudan ruang publik untuk melakukan kegiatan komunikasi dan informasi. Penelitian ini ingin memahami terkait fenomena layanan informasi yang dilakukan oleh Badan Publik dalam konteks pemenuhan kewajiban terhadap hak masyarakat dalam memperoleh informasi. Serta keterlibatan publik untuk berpartisipasi mendapatkan informasi tersebut sekaligus sebagai ruang dalam melakukan kontrol sosial terhadap penyelenggaraan pemerintah.

Layanan keterbukaan informasi publik sesunggunya dapat mendorong pada perbaikan layanan, peningkatan kinerja dan akutanbilitas program-program yang dijalankannya. Kabupaten Bangka telah membuka dan memberikan akses yang seluas-luasnya bagi publik untuk mendapatkan informasi meski terkesan belum terlalu maksimal tapi dirasakan sudah cukup siap dalam pemenuhan hak-hak untuk tahu bagi masyarakat Kab. Bangka. Pastisipasi publik dalam memanfaatkan akses mendapatkan informasi tersebut terlihat tidak terlalu maksimal. Partisipasi publik dalam mendapatkan informasi masih pasif, dengan memanfaatkan apa sudah disediakan oleh media. Sehingga kebutuhan informasi masyarakat di Kabupaten Bangka hanya berdasarkan kepada agenda media dan agenda kebijakan tidak kepada agenda publik. Berdasarkan hal tersebut disarankan kepada Pemerintah Kabupaten Bangka untuk melakukan sosialisasi kepada masyarakat secara masif dalam meningkatkan partisipasi aktif publik dalam memenuhi kebutuhan mereka terhadap informasi. Dan kepada masyarakat agar dapat menggunakan hak tahunya dengan maksimal sebagai bentuk partisipasi aktif dalam pembangunan daerah.
\end{abstract}

Kata Kunci: Layanan, Komunikasi, Informasi, Publik 


\section{PENDAHULUAN}

Layanan informasi publik merupakan satu konsep dasar pemerintah untuk melaksanakan amanat Undang-Undang 1945, dalam menyiapkan segala akses komunikasi dan informasi dengan menyediakan segala jenis saluran yang tersedia. Baik melalui media pos dan telekomunikasi, penyiaran, media komunikasi sosial dan media massa serta berbagai media yang bersifat interpersonal sebagai bagian dari perwujudan ruang publik untuk melakukan kegiatan komunikasi dan informasi.

Secara konseptual otonomi daerah berdasarkan Undang-undang 23 Tahun 2014 tentang pemerintah daerah yang mengatur pembagian kewenangan antara pusat, propinsi dan kabupaten/kota, telah memberikan tanggung jawab kepada pemerintah daerah untuk menjalankan kewenangannya sendiri dalam melakukan pembangunan yang seluas-luasnya, nyata dan bertanggung jawab secara profesional.

Paradigma dibidang komunikasi dan informasi menempatkan komunikasi dan informasi pada posisi yang sangat penting dan merupakan pemenuhan hak asasi manusia. Seperti yang tercantum dalam UUD 1945 pasal 28f menyatakan bahwa setiap orang berhak berkomunikasi dan memperoleh informasi untuk mengembangkan pribadi dan lingkungan sosialnya, serta berhak untuk mencari, memperoleh, memiliki, menyimpan, mengelola dan menyampaikan informasi dengan menggunakan segala jenis saluran yang tersedia.

Fenomena ini ditandai dengan semakin meningkatnya kesadaran masyarakat terhadap hak dan kewajibanya untuk berkomunikasi dan memperoleh beragam informasi dalam upaya mengembangkan pribadi dan lingkungan sosialnya.
Dalam pasal 28f tersebut juga dinyatakan bahwa perlindungan kemajuan, penegakan dan pemenuhan hak tersebut merupakan tanggungjawab negara terutama pemerintah, oleh karena itu dalam hal komunikasi dan informasi pemerintah bertanggungjawab terhadap penyiapan segala akses komunikasi dan informasi dengan menyediakan segala jenis saluran yang tersedia baik melalui media pos dan telekomunikasi, penyiaran, media komunikasi sosial dan media massa serta berbagai media yang bersifat interpersonal sebagai bagian dari perwujudan ruang publik untuk melakukan kegiatan komunikasi dan informasi di seluruh wilayah Indonesia baik tingkat nasional maupun lokal dan perdesaan.

Demikian juga halnya dengan pelaksanaan Undang-Undang No. 14 Tahun 2008 tentang keterbukaan informasi publik mengamanatkan kebebasan bagi masyarakat untuk mengakses informasi yang berkaitan erat dengan penyelenggaraan pemerintahan.

Informasi publik adalah informasi yang dihasilkan, disimpan, dikelola, dikirim, dan/atau diterima oleh suatu badan publik yang berkaitan dengan penyelenggara dan penyelenggaraan negara dan/atau penyelenggara dan penyelenggaraan badan publik lainnya yang sesuai dengan Undang-Undang ini serta informasi lain yang berkaitan dengan kepentingan publik.

Informasi merupakan kebutuhan setiap orang bagi pengembangan pribadi dan lingkungan sosialnya, serta merupakan bagian penting bagi ketahanan nasional. Hak memperoleh informasi merupakan hak asasi manusia dan keterbukaan informasi publik merupakan salah satu ciri penting negara demokratis yang menjunjung tinggi kedaulatan rakyat untuk mewujudkan penyelenggaraan negara yang baik.

Keterbukaan informasi publik merupakan sarana dalam mengoptimalkan pengawasan 
publik terhadap penyelenggaraan negara dan badan publik lainnya dan segala sesuatu yang berakibat pada kepentingan publik. Layanan informasi publik dalam rangka pemenuhan hak masyarakat tersebut berbanding tegak lurus dengan keterlibatan publik untuk berpartisipasi mendapatkan informasi tersebut.

Pemenuhan kebutuhan informasi publik tersebut tentunya tidak akan berjalan dengan maksimal tanpa partisipasi masyarakat dalam mendapatkan informasi, meskipun telah disediakan dan disiapkan. Dengan partisipasi tersebut diharapkan dapatmendorong peningkatan kemampuan pemberdayaan masyarakat dalam mencerdaskan publik.

Beranjak dari latar belakang di atas, tulisan ini akan mengulas fenomena terkait layanan komunikasi publik dan partisipasi publik khususnya dalam peran serta masyarakat untuk mendapatkan informasi pembangunan.

\section{Signifikansi}

Secara akademik hasil penelitian ini diharapkan dapat melengkapi informasi ilmiah yang sudah ada berkaitan dengan analisis informasi. Secara praktis diharapkan berguna bagi pemerintah daerah dan masyarakat dalam memberikan dan memperoleh informasi publik.

\section{ANALISIS}

\section{Pelayanan Informasi Publik}

Berdasarkan Undang-Undang Republik Indonesia pasal 1 Nomor 25 Tahun 2009 tentang Pelayanan Publik, pelayanan publik adalah kegiatan atau rangkaian kegiatan dalam rangka pemenuhan kebutuhan pelayanan sesuai dengan peraturan perundang-undangan bagi setiap warga negara dan penduduk atas jasa, barang, dan/atau pelayanan administratif yang disediakan oleh penyelenggara pelayanan publik.

Sementara itu berdasarkan Keputusan

\section{Menteri}

Pendayagunaan

Aparatur

Negara No.63/KEP/M.PAN/7/2003, pelayanan publik adalah segala kegiatan pelayanan yang dilaksanakan oleh penyelenggara pelayanan publik sebagai upaya pemenuhan kebutuhan penerima pelayanan maupun pelaksanaan ketentuan peraturan perundang-undangan.

Lain halnya menurut Ridwan dan Sudrajat (2009:19) pelayanan publik merupakan pelayanan yang diberikan oleh pemerintah sebagai penyelenggara negara terhadap masyarakat nya guna memenuhi kebutuhan dari masyarakat itu sendiri dan memiliki tujuan untuk meningkatkan kesejahteraan masyarakat.

Informasi menurut Undang-Undang No. 14 Tahun 2008 keterangan, pernyataan, gagasan, dan tanda-tanda yang mengandung nilai, makna, dan pesan, baik data, fakta maupun penjelasannya yang dapat dilihat, didengar, dan dibaca yang disajikan dalam berbagai kemasan dan format sesuai dengan perkembangan teknologi informasi dan komunikasi secara elektronik ataupun nonelektronik.

Sedangkan informasi publik adalah informasi yang dihasilkan, disimpan, dikelola, dikirim, dan/atau diterima oleh suatu badan publik yang berkaitan dengan penyelenggara dan penyelenggaraan negara dan/atau penyelenggara dan penyelenggaraan badan publik lainnya yang sesuai dengan Undang-Undang ini serta informasi lain yang berkaitan dengan kepentingan publik.

Badan Publik adalah lembaga eksekutif, legislatif, yudikatif, dan badan lain yang fungsi dan tugas pokoknya berkaitan dengan penyelenggaraan negara, yang sebagian atau seluruh dananya bersumber dari Anggaran Pendapatan dan Belanja Negara dan/atau Anggaran Pendapatan dan Belanja Daerah, atau organisasi nonpemerintah sepanjang sebagian atau seluruh dananya bersumber dari Anggaran Pendapatan dan Belanja Negara dan/ 
atau Anggaran Pendapatan dan Belanja Daerah, sumbangan masyarakat, dan/atau luar negeri.

Komisi Informasi adalah lembaga mandiri yang berfungsi menjalankan Undang-Undang ini dan peraturan pelaksanaannya, menetapkan petunjuk teknis standar layanan informasi publik dan menyelesaikan sengketa informasi publik melalui mediasi dan/atau ajudikasi nonlitigasi. 5. Sengketa Informasi Publik adalah sengketa yang terjadi antara badan publik dan pengguna informasi publik yang berkaitan dengan hak memperoleh dan menggunakan informasi berdasarkan perundang-undangan.

Pejabat Publik adalah orang yang ditunjuk dan diberi tugas untuk menduduki posisi atau jabatan tertentu pada badan publik. Pejabat Pengelola Informasi dan Dokumentasi adalah pejabat yang bertanggung jawab di bidang penyimpanan, pendokumentasian, penyediaan, dan/atau pelayanan informasi di badan publik.

Pengguna Informasi Publik adalah orang yang menggunakan informasi publik sebagaimana diatur dalam Undang-Undang ini. Pemohon Informasi Publik adalah warga negara dan/ atau badan hukum Indonesia yang mengajukan permintaan informasi publik sebagaimana diatur dalam Undang-Undang ini.

\section{Partisipasi Publik}

Menurut Ach. Wazir Ws., et al. (1999: 29) partisipasi bisa diartikan sebagai keterlibatan seseorang secara sadar ke dalam interaksi sosial dalam situasi tertentu. Dengan pengertian itu, seseorang bisa berpartisipasi bila ia menemukan dirinya dengan atau dalam kelompok, melalui berbagai proses berbagi dengan orang lain dalam hal nilai, tradisi, perasaan, kesetiaan, kepatuhan dan tanggungjawab bersama.

Partisipasi masyarakat menurut Isbandi (2007: 27) adalah keikutsertaan masyarakat dalam proses pengidentifikasian masalah dan potensi yang ada di masyarakat, pemilihan dan pengambilan keputusan tentang alternatif solusi untuk menangani masalah, pelaksanaan upaya mengatasi masalah, dan keterlibatan masyarakat dalam proses mengevaluasi perubahan yang terjadi.

Mikkelsen (1999: 64) membagi partisipasi menjadi 6 (enam) pengertian, yaitu:

1. Partisipasi adalah kontribusi sukarela dari masyarakat kepada proyek tanpa ikut serta dalam pengambilan keputusan;

2. Partisipasi adalah "pemekaan" (membuat peka) pihak masyarakat untuk meningkatkan kemauan menerima dan kemampuan untuk menanggapi proyekproyek pembangunan;

3. Partisipasi adalah keterlibatan sukarela oleh masyarakat dalam perubahan yang ditentukannya sendiri;

4. Partisipasi adalah suatu proses yang aktif, yang mengandung arti bahwa orang atau kelompok yang terkait, mengambil inisiatif dan menggunakan kebebasannya untuk melakukan hal itu;

5. Partisipasi adalah pemantapan dialog antara masyarakat setempat dengan para staf yang melakukan persiapan, pelaksanaan, monitoring proyek, agar supaya memperoleh informasi mengenai konteks lokal, dan dampak-dampak sosial;

6. Partisipasi adalah keterlibatan masyarakat dalam pembangunan diri, kehidupan, dan lingkungan mereka.

Pentingnya partisipasi dikemukakan oleh Conyers(1991:154-155)sebagaiberikut:pertama, partisipasi masyarakat merupakan suatu alat guna memperoleh informasi mengenai kondisi, 
kebutuhan, dan sikap masyarakat setempat, yang tanpa kehadirannya program pembangunan serta proyek-proyek akan gagal; kedua, bahwa masyarakat akan lebih mempercayai proyek atau program pembangunan jika merasa dilibatkan dalam proses persiapan dan perencanaannya, karena mereka akan lebih mengetahui selukbeluk proyek tersebut dan akan mempunyai rasa memiliki terhadap proyek tersebut; ketiga, bahwa merupakan suatu hak demokrasi bila masyarakat dilibatkan dalam pembangunan masyarakat mereka sendiri.

Adapun prinsip-prinsip partisipasi tersebut, sebagaimana tertuang dalam Panduan Pelaksanaan Pendekatan Partisipatif yang disusun oleh Department for International Development (DFID) dalam Monique Sumampouw (2004: 106-107) adalah:

a) Cakupan. Semua orang atau wakil-wakil dari semua kelompok yang terkena dampak dari hasil-hasil suatu keputusan atau proses proyek pembangunan.

b) Kesetaraan dan kemitraan (Equal Partnership). Pada dasarnya setiap orang mempunyai keterampilan, kemampuan dan prakarsa serta mempunyai hak untuk menggunakan prakarsa tersebut terlibat dalam setiap proses guna membangun dialog tanpa memperhitungkan jenjang dan struktur masing-masing pihak.

c) Transparansi. Semua pihak harus dapat menumbuhkembangkan komunikasi dan iklim berkomunikasi terbuka dan kondusif sehingga menimbulkan dialog.

d) Kesetaraan kewenangan (Sharing Power/ Equal Powership). Berbagai pihak yang terlibat harus dapat menyeimbangkan distribusi kewenangan dan kekuasaan untuk menghindari terjadinya dominasi.

e) Kesetaraan Tanggung Jawab (Sharing Responsibility). Berbagai pihak mempunyai tanggung jawab yang jelas dalam setiap proses karena adanya kesetaraan kewenangan (sharing power) dan keterlibatannya dalam proses pengambilan keputusan dan langkahlangkah selanjutnya.

f) Pemberdayaan (Empowerment). Keterlibatan berbagai pihak tidak lepas dari segala kekuatan dan kelemahan yang dimiliki setiap pihak, sehingga melalui keterlibatan aktif dalam setiap proses kegiatan, terjadi suatu proses saling belajar dan saling memberdayakan satu sama lain.

g) Kerjasama. Diperlukan adanya kerja sama berbagai pihak yang terlibat untuk saling berbagi kelebihan guna mengurangi berbagai kelemahan yang ada, khususnya yang berkaitan dengan kemampuan sumber daya manusia.

\section{Bentuk dan Tipe Partisipasi}

Ada beberapa bentuk partisipasi yang dapat diberikan masyarakat dalam suatu program pembangunan, yaitu partisipasi uang, partisipasi harta benda, partisipasi tenaga, partisipasi keterampilan, partisipasi buah pikiran, partisipasi sosial, partisipasi dalam proses pengambilan keputusan, dan partisipasi representatif.

Dengan berbagai bentuk partisipasi yang telah disebutkan diatas, maka bentuk partisipasi dapat dikelompokkan menjadi 2 jenis, yaitu bentuk partisipasi yang diberikan dalam bentuk nyata (memiliki wujud) dan juga bentuk partisipasi yang diberikan dalam bentuk tidak nyata (abstrak). Bentuk partisipasi yang nyata misalnya uang, harta benda, tenaga dan keterampilan sedangkan bentuk partisipasi yang tidak nyata adalah partisipasi buah pikiran, partisipasi sosial, pengambilan keputusan dan partisipasi representatif.

Partisipasi buah pikiran lebih merupakan partisipasi berupa sumbangan ide, pendapat atau buah pikiran konstruktif, baik untuk menyusun 
program maupun untuk memperlancar pelaksanaan program dan juga untuk mewujudkannya denganmemberikan pengalaman dan pengetahuan guna mengembangkan kegiatan yang diikutinya.

Partisipasi sosial diberikan oleh partisipan sebagai tanda paguyuban. Misalnya arisan, menghadiri kematian, dan lainnya dan dapat juga sumbangan perhatian atau tanda kedekatan dalam rangka memotivasi orang lain untuk berpartisipasi.

Pada partisipasi dalam proses pengambilan keputusan, masyarakat terlibat dalam setiap diskusi/forum dalam rangka untuk mengambil keputusan yang terkait dengan kepentingan bersama. Sedangkan partisipasi representatif dilakukan dengan cara memberikan kepercayaan/ mandat kepada wakilnya yang duduk dalam organisasi atau panitia.

Selanjutnya menurut Slamet (2003: 8 ) menyatakan bahwa, partisipasi Valderama dalam Arsito mencatat ada tiga tradisi konsep partisipasi terutama bila dikaitkan dengan pembangunan masyarakat yang demokratis yaitu:

1. Partisipasi politik (political participation) lebih berorientasi pada "mempengaruhi" dan "mendudukan wakil-wakil rakyat" dalam lembaga pemerintah ketimbang partisipasi aktif dalam proses-proses kepemerintahan itu sendiri.

2. Partisipasi sosial (social participation) ditempatkan sebagai beneficiary atau pihak diluar proses pembangunan dalam konsultasi atau pengambilan keputusan dalam semua tahapan siklus proyek pembangunan dari evaluasi kebutuhan sampai penilaian, pemantauan, evaluasi dan implementasi. Partisipasi sosial sebenarnya dilakukan untuk memperkuat proses pembelajaran dan mobilisasi sosial. Dengan kata lain, tujuan utama dari proses sosial sebenarnya bukanlah pada kebijakan publik itu sendiri tetapi keterlibatan komunitas dalam dunia kebijakan publik lebih diarahkan sebagai wahana pembelajaran dan mobilisasi sosial.

3. Partisipasi warga (citizen participation/ citizenship) menekankan pada partisipasi langsung warga dalam pengambilan keputusan pada lembaga dan proses pemerintahan. Partisipasi warga telah mengalih konsep partisipasi "dari sekedar kepedulian terhadap penerima derma atau kaum tersisih menuju suatu kepedulian dengan berbagai bentuk keikutsertaan warga dalam pembuatan kebijakan dan pengambil keputusan di berbagai gelanggang kunci yang mempengaruhi kehidupan mereka. Maka berbeda dengan partisipasi sosial, partisipasi warga memang berorientasi pada agenda penentuan kebijakan publik.

Sedangkan menurut Holil (1980: 9-10), unsur-unsur dasar partisipasi sosial yang juga dapat mempengaruhi partisipasi masyarakat adalah:

1. Kepercayaan diri masyarakat;

2. Solidaritas dan integritas sosial masyarakat;

3. Tanggungjawab sosial dan komitmen masyarakat;

4. Kemauan dan kemampuan untuk mengubah atau memperbaiki keadaan dan membangun atas kekuatan sendiri;

5. Prakarsa masyarakat atau prakarsa perseorangan yang diterima dan diakui sebagai/menjadi milik masyarakat;

6. Kepentingan umum murni, setidaktidaknya umum dalam lingkungan masyarakat yang bersangkutan, dalam 
pengertian bukan kepentingan umum yang semu karena penunggangan oleh kepentingan perseorangan atau sebagian kecil dari masyarakat;

7. Organisasi, keputusan rasional dan efisiensi usaha;

8. Musyawarah untuk mufakat dalam pengambilan keputusan;

9. Kepekaan dan ketanggapan masyarakat terhadap masalah, kebutuhan-kebutuhan dan kepentingan-kepentingan umum masyarakat.

Faktor yang mempengaruhi partisipasi masyarakat dalam suatu program juga dapat berasal dari unsur luar/lingkungan. Menurut Holil (1980: 10) ada 4 poin yang dapat mempengaruhi partisipasi masyarakat yang berasal dari luar/ lingkungan, yaitu:

1. Komunikasi yang intensif antara sesama warga masyarakat, antara warga masyarakat dengan pimpinannya serta antara sistem sosial di dalam masyarakat dengan sistem di luarnya;

2. Iklim sosial, ekonomi, politik dan budaya, baik dalam kehidupan keluarga, pergaulan, permainan, sekolah maupun masyarakat dan bangsa yang menguntungkan bagi serta mendorong tumbuh dan berkembangnya partisipasi masyarakat;

3. Kesempatan untuk berpartisipasi. Keadaan lingkungan serta proses dan struktur sosial, sistem nilai dan normanorma yang memungkinkan dan mendorong terjadinya partisipasi sosial;

4. Kebebasan untuk berprakarsa dan berkreasi. Lingkungan di dalam keluarga masyarakat atau lingkungan politik, sosial, budaya yang memungkinkan dan mendorong timbul dan berkembangnya prakarsa, gagasan, perseorangan atau kelompok.

\section{METODE}

Penelitian ini menggunakan metodologi kualitatif dimana mencoba mendeskripsikan layananpemberianinformasi publik danpartisipasi publik. Pengumpulan data dilakukan dengan empat sumber, yaitu wawancara, observasi, arsip dan dokumen. Observasi dilakukan untuk memperoleh pemahaman mengenai proses, tindakan dan kegiatan pelayanan yang dilakukan dan partisipasi publik. Arsip diperoleh melalui data internal lembaga seperti rencana strategis, dokumen permohonan dll.

\section{HASIL DAN PEMBAHASAN}

Kabupaten Bangka yang memiliki daerah seluas 2.950, $68 \mathrm{Km} 2$ dan terdiri dari 242.010 jiwa penduduk, relatif besar dibandingkan kabupaten lain di daerah Provinsi Kepulauan Bangka Belitung. Dalam rangka pemerataan hasil pembangunan, maka pelayanan dan jangkauan komunikasi dan informasi diharapkan dapat menjangkau seluruh daerah dalam Kabupaten Bangka, serta merupakan sarana komunikasi dengan dunia luar.

Kondisi pelayanan informasi publik di Kabupaten Bangka dimulai dengan adanya pelayanan terbatas telepon kabel oleh PT. Timah Tbk, pos, media cetak lokal dan nasional (Suara Pembaharuan, Kompas, Suara Karya, Majalah Kartini, Femina, Ananda, Kuncung, Bobo dll), radio amatir, bioskop dan media tradisional (upacara adat,pantun, musik, cerita rakyat, nyanyian dll). 
Penyelenggaraan layanan informasi publik pada pemerintah Kabupaten Bangka, berdasarkan Peraturan Bupati Nomor 60 Tahun 2016 tentang Kedudukan, Susunan Organisasi, Tugas dan Fungsi Serta Tata Kerja Dinas Komunikasi, Informatika dan Statistik Kab. Bangka, serta Peraturan Peraturan Bupati Nomor 47 Tahun 2016 tentang Kedudukan, Susunan Organisasi, Tugas dan Fungsi Serta Tata Kerja Sekretariat Daerah Kab. Bangka. Dilaksanakan oleh Bidang Informasi dan Komunikasi Publik dan Bagian Protokol dan humas Setda Bangka.

Adapun strategi pembangunan bidang komunikasi dan informatika Kab. Bangka lima tahunan diarahkan kepada peningkatan sarana prasarana, kapasitas dan kualitas pelayanan dalam kerangka penyediaan aksesibilitas jasa komunikasi dan informatika. Yang berdasarkan pada lima pilar pembangunan yaitu :

1. Pembangunan kominfo dilakukan dengan partisipasi masyarakat dalam melakukan kontrol sosial sebagai dasar dalam penyelenggaraan pemerintahan yang bersih dengan memberikan akses mendapatkan informasi yang terbuka dan memiliki akutanbilitas yang tinggi;

2. Pembangunan kominfo dilakukan dengan pengembangan system tehnologi informasi dan kemitraan media bagi peningkatan pengembangan masyarakat dalam mendapatkan informasi publik yang mudah, terbuka, akurat dan dapat dipercaya;

3. Pembangunan kominfo dilakukan dengan pengembangan komunikasi sosial masyarakat, lembaga masyarakat dan pemerintah daerah yang besinergi dana berimbang serta berperan aktif dalam penyelenggaraan, pengawasan dan pengendalian;
4. Pembangunan kominfo berdasarkan azas manfaat untuk mendorong pengembangan sosial, budaya, politik dan ekonomi dalam mendukung program pembangunan pemerintah daerah dan pusat;

5. Pembangunan kominfo dilakukan dengan orientasi peningkatan sarana prasarana fasilitas dan pelayanan kepada masyarakat dengan tehnologi dan professional aparatur yang memiliki kredibilitas yang tinggi.

Lima pilar strategi pembangunan tersebut kemudian diturunkan kepada arah kebijakan dalam pengembangan pelayanan kominfo di Kabupaten Bangka. Adapun lima langkah kebijakan tersebut Kabupaten Bangka yaitu:

1. Pengembangan sarana prasarana penyelenggaraan kominfo;

2. Pengembangan komunikasi pembangunan sosial, pemerintah daerah, pusat dengan pengembangan kemitraan media lokal dan nasional;

3. Pengelolaan layanan informasi publik dalam keterbukaan informasi publik ;

4. Mendorong peran serta masyarakat dan swasta dalam pengembangan penyelenggaraan kominfo;

5. Peningkatan professional aparatur dengan penguasaan tehnologi informasi, komunikasi dan hukum.

Lima langkah kebijakan yang telah ditetapkan oleh Pemkab. Bangka tersebut dalam rangka mendukung program pemerintah menuju masyarakat informasi. Sebagaimana diamanatkan dalam UU No. 17 Tahun 2007 tentang Rencana Pembangunan Jangka Panjang Nasional 2005-2025, Masyarakat Informasi Indonesia diproyeksikan terwujud pada periode 
jangka menengah ketiga, yaitu tahun 2015-2019.

Sasaran Pemerintah sudah ditentukan yaitu meningkatkan kemampuan sumber manusia Indonesia untuk mendapatkan, mengolah dan memanfaatkan informasi terkini, sehingga diharapkan akan meningkatkan pertumbuhan ekonomi dan daya saing manusia Indonesia. Dengan sasaran seperti itu maka perlu dibangun berbagai fasilitas komunikasi dan informatika sampai pelosok wilayah Indonesia.

\section{Daftar Informasi Publik (DIP)}

Pemerintah Kaupaten Bangka dalam menyelenggarakan layanan informasi publik sebelum keluar UU keterbukaan informasi publik, dilakukan dengan terbatas pada informasi yang memang disiapkan untuk kosumsi publik artinya adalah bahwa pesan-pesan telah distrukturisasi yang mengaitkan berbagai kepentingan.

Menurut Sumarno dkk (2009:9) transaksi komunikasi yang berlangsung secara komplementer sehingga tidak ada satu pihak pun yang merasa dirugikan. Hak berkomunikasi selalu berdampingan dengan tanggungjawab moral sebagai dasar ayoman terhadap semua kepentingan.

Sehingga layanan informasi yang diberikan bertujuan kepada terciptanya opini publik yang baik dan bersifat informasi satu arah dengan menggunakan berbagai media yang ada baik itu media lini atas maupun media lini bawah.

Kompleksnya layanan informasi yang harus ditangani karena bersangkutan paut dengan sikap budaya, ekonomi, sosial dan politik yang menyebabkan terkendalanya jangkauan intensitas, diseminasi informasi dan kesinambungan pelancaran arus informasi, khususnya menyangkut informasi kebijakan pemerintahan yang harus segera diketahui masyarakat.

Dalam cangkupan ideal komunikasi, maka hak-hak komunikasi menurut Sumarno dkk. $(2009 ; 9)$ tidak dapat digunakan secara mutlak atau sebaliknya hak-hak berkomunikasi tidak dapat dibatasi ruang geraknya terutama sumbersumber komunikasi yang berada dalam struktur kekuasaan. Hak berkomunikasi harus tetap berada dalam lingkaran-lingkaran normatif yang memberikan manfaat dalam kehidupan manusia.

Kemudian dengan keluarnya UndangUndang No. 14 Tahun 2018 tentang keterbukaan informasi publik, mensyaratkan semua badan publik harus memberikan layanan informasi publik secara terbuka, cepat dan mudah di jangkau. Hal tersebut berimplikasi kepada merekstruktur pesan. Sehingga layanan informasi harus dilakukan secara sistematis, terstruktur dan terbuka.

Badan publik dituntut untuk segera membuat struktur lembaga pengelola layanan informasi publik (PLID) dan membuat daftar informasi publik, seperti tabel dibawah ini: 
Tabel 1. Klasifikasi informasi

\begin{tabular}{|c|c|c|c|}
\hline $\begin{array}{l}\text { Informasi yang Wajib } \\
\text { disediakan \& diumumkan }\end{array}$ & $\begin{array}{l}\text { Infor'masi yang wa- } \\
\text { jib Diumumkan secara } \\
\text { Serta merta }\end{array}$ & 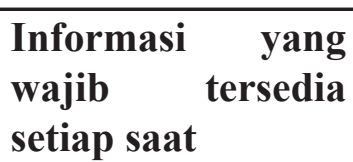 & $\begin{array}{l}\text { Informasi yang wa- } \\
\text { jib tersedia setiap } \\
\text { saat }\end{array}$ \\
\hline $\begin{array}{l}\text { - Informasi yang berkaitan } \\
\text { dgn badan publik; } \\
\text { - Informasi mengenai keg- } \\
\text { iatan \& kinerja badan } \\
\text { publik terkait; } \\
\text { - Informasi mengenai } \\
\text { laporan keuangan; } \\
\text { - Informasi yang diatur } \\
\text { dalam perundang-un- } \\
\text { dangan. }\end{array}$ & $\begin{array}{l}\text { Informasi yang da- } \\
\text { pat mengancam hajat } \\
\text { hidup orang banyak } \\
\text { dan ketertiban umum. } \\
\text { (bencana alam, benca- } \\
\text { na non alam, bencana } \\
\text { sosial, pesebaran epi- } \\
\text { demi penyakit, racun } \\
\text { pd bahan makanan } \\
\text { \& informasi rencana } \\
\text { gangguan utilitas pub- } \\
\text { lik) }\end{array}$ & $\begin{array}{l}\text { - Daftar informasi } \\
\text { publik dalam pen- } \\
\text { guasaan; } \\
\text { - Hasil keputusan \& } \\
\text { pertimbangan; } \\
\text { - Seluruh kebijakan } \\
\text { yg ada \& doku- } \\
\text { menya; } \\
\text { - Renja proyek \& } \\
\text { RAB; } \\
\text { - Perjanjian dgn } \\
\text { pihak ke.3; } \\
\text { - Informasi \& kebi- } \\
\text { jakan yng disam- } \\
\text { paikan dalam per- } \\
\text { temuan terbuka; } \\
\text { - Alur kerja/SOP; } \\
\text { - Laporan pelay- } \\
\text { anan akses infor- } \\
\text { masi publik sesuai } \\
\text { dengan UU. }\end{array}$ & $\begin{array}{l}\text { - Informasi yg da- } \\
\text { pat menghambat } \\
\text { proses penega- } \\
\text { kan hukum; } \\
\text { - Informasi yg da- } \\
\text { pat mengganggu } \\
\text { kepentingan per- } \\
\text { lindungan hak } \\
\text { atas kekayaan in- } \\
\text { telektual \& per- } \\
\text { saingan usaha; } \\
\text { - Informasi yang } \\
\text { membahayakan } \\
\text { pertahanan \& } \\
\text { keamanan; } \\
\text { - Informasi yang } \\
\text { menguangkapan } \\
\text { kekayaan alam; } \\
\text { - Informasi yang } \\
\text { dapat merugikan } \\
\text { ketahanan ekono- } \\
\text { mi nasional; } \\
\text { - Informasi yang } \\
\text { m e r u g k a n } \\
\text { hubungan luar } \\
\text { negeri; } \\
\text { - Informasi pribadi } \\
\text { \& rahasia priba- } \\
\text { di; } \\
\text { hurat menasi rahasia } \\
\text { yang sifatnya ra- } \\
\text { hasia; UU. }\end{array}$ \\
\hline
\end{tabular}

(Sumber: UU No. 14 Tahun 2008) 
Setiap badan publik, harus membuat klasifikasi informasi tersebut sebagai acuan dalam memberikan layanan informasi publik. Klasifikasi informasi tersebut selain memudahkan juga sebagai dasar dalam memberikan pertimbangan apakah permohonan informasi tersebut dapat diberikan atau dikabulkan.

Pemerintah Kabupaten Bangka telah menyusun daftar informasi publik (DIP) tersebut berdasarkan tugas dan pokok serta kebijakan organisasi perangkat daerah (OPD) masingmasing. Tapi terlihat bahwa pengklasifikasian yang dilakukan belum terlalu maksimal, daftar yang dibuat baru seadanya dan tergantung kepada permohonan informasi yang ada, baru kemudian disiapkan.

Keterbatasan dalam menyusun klasifikasi tersebut dikarenakan terbatasnya jumlah sumber daya yang tersedia, baik SDM yang profesional di bidang komunikasi dan informatika maupun sarana dan prasarana yang memadai. Kecenderungan masih adanya penafsiran yang sempit terhadap keterbukaan informasi sehingga sering terjadi penolakan terhadap permohonan informasi yang berujung kepada sengketa informasi.

Dalam pertemuan penjabat pengelola informasi dan dokumentasi daerah di Propinsi pada bulan Maret lalu, terlihat bahwa masih banyak badan publik yang tidak mengerti bagaimana membuat klasifikasi informasi, terutama informasi yang dikecualikan atau informasi yang tidak bisa diberikan berdasar atuaran dan perundang-undangan.

Selain itu dalam pelaksanaan pengelola layanan informasi publik masih ada dualisme dalam menafsiran Permendagri No. 3 Tahun 2017 tentang siapa yang menjadi pengelola layanan tersebut yaitu antara bagian humas pada setda dan bidang inbformasi dan komunikasi publik pada dinas kominfo. Sehingga kemudian setiap daerah akan berbeda-beda pengelolaannya dan terjadi tumpah tindih kewenangan. Masalah yang memiliki nilai signifikansi yang tinggi dalam mempengaruhi layanan informasi publik.

Masih belum dipahaminya secara filosofis maupun praktis mengenai perubahan paradigma komunikasi dan informatika yang dikembangkan masa reformasi seperti:

a. Pemahaman terhadap hak publik mengenai komunikasi dan informasi

b. kemerdekaan pers yang diatur dalam UndangUndang No. 40 Tahun 1999.

c. Undang-Undang No. 32 Tahun 2014 yaitu mengatur kewenangan yang disentralisasikan dan pembentukan kelembagaannya diserahkan ke daerah.

d. Peraturan Pemerintah No. 18 Tahun2016, yang mengatur tentang salah satu urusan wajib yang harus ditangani oleh pemerintah daerah dan kelembagaannya.

Membuat pemerintah pusat dan daerah serta jajarannya harus selalu berkoordinasi dan terintegrasi untuk menyamakan persepsi dalam meletakan landasan untuk melakukan pembangunan di bidang ini.

Salah satu konsekuensi untuk mengantisipasi dalam melakukan pelayanan prima adalah kesiapan sumber daya manusia. Semakin kompleksnya permasalahan komunikasi dan informasi dewasa ini, maka dibutuhkan suatu kemampuan dan keahlian aparatur guna mendukung kebijakan daerah yang sejalan dengan kebijakan pusat dalam mengatur pengembangan dunia komunikasi dan Informasi sebagai salah satu fungsi melaksanakan kewenangan dan desentralisasi, sesuai dengan Undang-Undang No. 32 Tahun 2014.

Sejalan dengan hal tersebut kemajuan teknologi khususnya bidang komunikasi dan informasi menjadi pendukung globalisasi perekonomian dan pengembangan suatu daerah. Maka tuntutan 
pembangunan/pengembangan sarana, prasarana maupun pengelolaan jaringan komunikasi dan informatika dituntut agar dapat mengantisipasi pola dan itensitas pergerakan dari globalisasi tersebut.

Dengan adanya konsekuensi hukum yang akan diberikan kepada badan publik dalam melakukan layanan informasi, badan publik tidak memiliki peluang untuk menolak memberikan informasi yang diminta oleh publik sesuai dengan kebutuhan mereka. Demikian juga sebaliknya pengguna informasi yang tidak sesuai dengan peruntukannya akan mendapatkan hukum pidana dan denda.

Dengan membuka akses publik terhadap Informasi diharapkan badan publik termotivasi untuk bertanggung jawab dan berorientasi pada pelayanan rakyat yang sebaik-baiknya. Hal itu diyakini dapat mempercepat perwujudan pemerintahan yang terbuka yang merupakan upaya strategis mencegah praktik korupsi, kolusi, dan nepotisme (KKN), dan terciptanya pemerintahan yang baik (good governance).

\section{Partisipasi Publik dalam Keterbukaan Informasi Publik}

Pencerdasan masyarakat dalam menyiapkan dan memberikan akses informasi tentunya tidak akan maksimal tanpa keikutsertaan masyarakat dalam partisipasi mendapatkan informasi tersebut. Penempatan masyarakat sebagai subjek pembangunan mutlak diperlukan sehingga masyarakat akan dapat berperan serta secara aktif mulai dari perencanaan, pelaksanaan hingga monitoring dan evaluasi pembangunan.

Partisipasi publik menurut Ach. Wazir Ws., et al. (1999: 29) bisa diartikan sebagai keterlibatan seseorang secara sadar ke dalam interaksi sosial dalam situasi tertentu. Dengan pengertian itu, seseorang bisa berpartisipasi bila ia menemukan dirinya dengan atau dalam kelompok, melalui berbagai proses berbagi dengan orang lain dalam hal nilai, tradisi, perasaan, kesetiaan, kepatuhan dan tanggungjawab bersama.

Berdasarkan data yang didapat dari Dinkominfo Kabupaten Bangka, terlihat partisipasi masyarakat dalam melakukan permohonan informasi sangat minim sekali, tercatat pada tahun 2017 s.d 2017 hanya 10 permohonan, Dan yang kemudian menjadi sengketan informasi hanya 2 kasus. Setelah dilakukan observasi pada dokumen permohonan informasi yang melakukan permohonan informasi itu adalah orang yang sama, kalau pun ada nama lain yang muncul menurut petugas penerima permohonan adalah bagian dari kelompok yang sama. Dan terindikasi ada kelompok-kelompok yang memanfaatkan keterbukaan informasi publik tersebut demi kepentingan kelompok atau pribadi.

Menurut salah satu staf pelayanan, hampir rata-rata pemohon berprofesi koresponden/pers yang medianya tidak dikenal. Tapi memohon informasi dengan alasan uji akses, apakah badan publik menyiapkan informasi yang diminta oleh mereka.

"Kami memohon informasi untuk uji akses, sebagai masyarakat kami ingin tahu apakah pemkab Bangka telah melaksanakan UU KIP tersebut. Selain itukamijuga ingin tahu bagaimana pertanggungjawaban dari OPD masing-masing, ungkap salah satu pemohon informasi”.

Terlepas informasi tersebut mau digunakan untuk kepentingan apa dalam konteks profesinya tapi mereka telah menggunakan haknya untuk mendapatkan informasi, dan secara aktif melakukan kontrol sosial terhadap penyelenggaraan pemerintah.

Selanjutnya menurut Slamet ( 2003:8 ) 
partisipasi Valderama dalam Arsito mencatat ada tiga tradisi konsep partisipasi bila dikaitkan dengan pembangunan masyarakat yang demokratis yaitu partisipasi politik berorientasi kepada mempengaruhi dan mendudukan wakilnya ketimbang dalam proses pemeritah, partisipasi sosial adalah bagaimana keterlibatan komunitas dalam dunia kebijakan publik yang diarahkan sebagai wahana pembelajaran dan mobilisasi sosial.

Sedangkan partisipasi warga (participation/ citizenship) menekankan pada partisipasi langsung warga dalam pengambilan keputusan pada lembaga dan proses pemerintahan. Partisipasi warga telah mengalih konsep partisipasi "dari sekedar kepedulian terhadap penerima derma atau kaum tersisih menuju suatu keperdulian dengan berbagai bentuk keikutsertaan warga dalam pembuatan kebijakan dan pengambil keputusan diberbagai gelanggang kunci yang mempengaruhi kehidupan mereka. Maka berbeda dengan partisipasi sosial, partisipasi warga memang berorientasi pada agenda penentuan kebijakan publik.

Masyarakat Kabupaten Bangka dalam konteks pemenuhan kebutuhannya akan informasi cenderung memilih berpastisipasi pasif, artinya mereka memiliki informasi yang memang sudah disiapkan oleh media yang ada, dihantarkan dan mereka memilih serta memilah informasi apa yang ingin dikonsumsi. Tanpa bersusah payah untuk meminta informasi.Sehingga informasi apa yang dianggap penting oleh media, akan menjadi penting oleh masyarakat, yang kemudian menjadi penting buat kebijakan.

\section{KESIMPULAN}

Layanan keterbukaan informasi publik sesunggunya dapat mendorong pada perbaikan layanan, peningkatan kinerja dan akutanbilitas program-program yang dijalankannya. Kabupaten Bangka telah membuka dan memberikan akses yang seluas-luasnya bagi publik untuk mendapatkan informasi meskti terkesan belum terlalu maksimal tapi dirasakan sudah cukup siap dalam pemenuhan hak-hak untuk tahu bagi masyarakat Kabupaten Bangka.

Pastisipasi Publik dalam memanfaatkan akses mendapatkan informasi tersebut terlihat tidak terlalu maksimal. Partisipasi publik dalam mendapatkan informasi terlihat pasif, dengan memanfaatkan apa sudah disediakan oleh media. Sehingga kebutuhan informasi masyarakat di Kabupaten Bangka hanya berdasarkan kepada agenda media dan agenda kebijakan tidak kepada agenda publik.

Berdasarkan hal tersebut disarankan kepada Pemerintah Kabupaten Bangka untuk melakukan sosialisasi kepada masyarakat secara masiv dalam meningkatkan partisipasi aktif publik dalam memenuhi kebutuhan mereka terhadap informasi. Dan kepada masyarakat agar dapat menggunakan hak tahunya dengan maksimal sebagai bentuk partisipasi aktif dalam pembangunan daerah.

\section{DAFTAR PUSTAKA}

Ach. Wazir Ws., et al., ed. (1999). Panduan Penguatan Menejemen Lembaga Swadaya Masyarakat. Jakarta: Sekretariat Bina Desa dengan dukungan AusAID melalui Indonesia HIV/AIDS and STD Prevention and Care Project.

Abdul Muis, Communicating New Ideas to Traditional Villagers: an Indonesian Case, Media Asia 11, 1984.

Amri Jahi, Komunikasi Massa dan Pembangunan Pedesaan di Negara-Negara Dunia Ketiga, 
PT Gramedia, Jakarta, 1998.

Conyers, Diana. (1991). Perencanaan Sosial di Dunia ketiga. Yogyakarta: UGM Press.

Holil Soelaiman. (1980). Partisipasi Sosial dalam Usaha Kesejahteraan Sosial. Bandung. Isbandi Rukminto Adi. (2007). Perencanaan Partisipatoris Berbasis Aset Komunitas: dari Pemikiran Menuju Penerapan. Depok: FISIP UI Press.

Mikkelsen, Britha. (1999). Metode Penelitian Partisipatoris dan Upaya-upaya Pemberdayaan: sebuah buku pegangan bagi para praktisi lapangan. Jakarta: Yayasan Obor Indonesia.

Nurudin, Sistem Komunikasi Indonesia, PT Raja Grafindo Persada, Jakarta, 2004.

Ridwan, Juniarso \& Sodik Sudrajat Acmad, 2009, Hukum administrasi Negara \& Kebijakan Pelayanan Publik, Bandung, Nuansa;

Ranganath, 1976, Telling the People Tell Themselves, Media Asia 3

Rahmat, Jalalluddin, Psikologi Komunikasi, Rosdakarya, Bandung, 2007

Sumampouw, Monique. 2004. "Perencanaan Darat-Laut yang Terintegrasi dengan Menggunakan Informasi Spasial yang Partisipatif." Jacub Rais, et al. Menata Ruang Laut Terpadu. Jakarta: Pradnya Paramita. 91117.

Slamet, M. 2003. Membentuk Pola Perilaku Manusia Pembangunan. Bogor: IPB Press

Undang-Undang No. 14 Tahun 2008 tentang Keterbukaan Informasi Publik.

Undang-Undang No. 25 Tahun 2009 tentang Pelayanan Publik.

Undang-Undang No. 23 Tahun 2014 tentang Pemerintah Daerah;.

Peraturan Pemerintah No. 38 Tahun 2008
Tentang Pembagian Kewenangan antara Pusat, Propinsi dan Daerah.

Keputusan Menpan RB No. 63/Kep/m. Pan/7/2003 tentang Pelayanan Publik;

Pemerintah Propinsi Kepulauan Bangka Belitung, Kepulauan Bangka Belitung, Jakarta,2006.

Peraturan Daerah Kabupaten Bangka No. 9 Tahun 2016 Tentang Pembentukan dan Susunan Perangkat Daerah Pemerintah Daerah Pemerintah Kabupaten Bangka.

Keputusan Bupati Bangka No. 60 Tahun 2016 Tentang Kedudukan, Sususnan Organisasi, Tugas dan Fungsi Serta Tata Kerja Dinas Komunikasi, Informasi dasn Statistik Kabupaten Bangka.

Rencana Strategis Dinas Komunikasi, Informasi dan Statistik Kabupaten Bangka Tahun 200172015.

Rapat Koordinasi Bidang Komunikasi dan Informasi Propinsi Kepulauan Bangka Belitung, Pangkalpinang, 2018.

\section{Internet :}

http://id.wikipedia.org/wiki/Kepulauan Bangka_Belitung, diakses 18 April 2018. http://organisasi.org/arti-definisi-pengertianperkawinanpernikahan-dan-dasar-tujuan-nikahkawin-manusia, diakses 18 April 2018 http://www.bangka.go.id/content.php?id content $=$ kondisi geografis, diakses, 18 April 2018

http://www.bangka.go.id/content.php?id content=penduduk, diakses, 18 April 2018. 